\title{
PERAN PEMERINTAH DAERAH DALAM PENGELOLAAN WILAYAH PESISIR
}

Fikri Jamal

Fakultas Hukum Universitas Pamulang

Email : fikri.ganesa@gmail.com

Received: Feb 2019/Revised: Feb 19/ Accepted: Ags 2019

\begin{abstract}
Wilayah pesisir memiliki arti strategis karena merupakan wilayah peralihan antara ekosistem darat dan laut yang berkesinambungan. Di wilayah pesisir ini terdapat sumber daya pesisir berupa sumberdaya alam dan jasa lingkungan yang sangat kaya. Kekayaan sumberdaya pesisir tersebut menimbulkan daya tarik bagi berbagai pihak untuk mengeksploitasinya dan berbagai instansi berkepentingan untuk meregulasi pemanfaatannya.Wilayah pesisir terdapat berbagai ekosistem alami yang mempunyai fungsi masing-masing yang berlainan, yaitu misalnya hutan bakau, padang lamun, estuaria, delta, dan terumbu karang Sesuai dengan hakikat Negara Kesatuan Republik Indonesia sebagai negara hukum, pengembangan sistem Pengelolaan Wilayah Pesisir dan PulauPulau Kecil sebagai bagian dari pembangunan berkelanjutan yang berwawasan lingkungan hidup harus diberi dasar hukum yang jelas, tegas, dan menyeluruh guna menjamin kepastian hukum bagi upaya pengelolaan Wilayah Pesisir dan Pulau-Pulau Kecil.
\end{abstract}

Kata Kunci : Pemerintah Daerah, Wilayah Pesisir, Pulau-Pulau Kecil.

\begin{abstract}
Coastal areas have a strategic meaning because it is a transition region between the terrestrial and marine ecosystems are sustainable. In this coastal region there are coastal resources in the form of natural resources and environmental services are very rich. The richness of these coastal resources creates an attraction for various parties to exploit it and various agencies have an interest to regulate its utilization. Coastal areas contain natural ecosystems that have their own distinct functions, such as mangrove forests, seagrass beds, estuaries, deltas, and coral reefs In accordance with the nature of the Unitary State of the Republic of Indonesia as a constitutional state, the development of coastal management system and small islands as part of environmentally sustainable development should be given clear, firm and comprehensive legal basis to ensure legal certainty for coastal area management efforts and Small Islands

Keywords: Local Government, Coastal Area, Small Islands.
\end{abstract}


Fikri Jamal

\section{PENDAHULUAN}

Indonesia dilihat dari geografis merupakan negara dengan prosentase sebagian besar wilayahnya merupakan perairan yang tergugus pulau-pulau besar dan kecil.Secara geografis letak kepulauan Indonesia sangat strategis yakni di daerah tropis yang diapit oleh dua benua (Asia dan Australia), dua samudera (Pasifik dan India), serta merupakan pertemuan tiga lempeng besar di dunia (Eurasia, India-Australia dan Pasifik) menjadikan kepulauan Indonesia dikaruniai kekayaan sumberdaya kelautan yang berlimpah, baik berupa sumberdaya hayati dan non-hayati, maupun jasajasa lingkungan.

Memperhatikan konteks nasional mengenai bentuk negara yang ada, Indonesia adalah negara kepulauan yang memiliki lebih dari 17.508 pulau dengan luas wilayah perairan laut lebih dari $75 \%$ dan panjang garis pantai mencapai 81.00o km. Dengan demikian, pengelolaan sumber daya pesisir dan laut secara berkelanjutan merupakan bagian penting dalam strategi pembangunan untuk meningkatkan daya saing nasional. ${ }^{1}$

Luas daratan Indonesia mencapai 1,9 juta $\mathrm{km}^{2}$ dan luas perairan laut kurang lebih 7,9 juta $\mathrm{km}^{2}$. Sebanyak 22 persen dari total penduduk Indonesia mendiami wilayah pesisir. Ini berarti bahwa daerah pesisir merupakan salah satu pusat kegiatan ekonomi nasional melalui kegiatan masyarakat seperti perikanan laut, perdagangan, budidaya perikanan (aquakultur), transportasi, pariwisata, pengeboran minyak dan sebagainya.

Sesuai dengan hakikat Negara Kesatuan Republik Indonesia sebagai negara hukum, pengembangan sistem Pengelolaan Wilayah Pesisir dan Pulau-Pulau Kecil sebagai bagian dari pembangunan berkelanjutan yang berwawasan lingkungan hidup harus diberi dasar hukum yang jelas, tegas, dan menyeluruh guna menjamin kepastian hukum bagi upaya pengelolaan Wilayah Pesisir dan Pulau-Pulau Kecil untuk itulah dikeluarkannya Undang-Undang Nomor I Tahun 2014 Tentang Perubahan Atas UndangUndang Nomor 27 Tahun 2007 Tentang Pengelolaan Wilayah Pesisir dan Pulau-pulau Kecil sebagai sebuah lex specialis dalam pengelolaan dan perlindungan wilayah pesisir dan pulau kecil di Indonesia.

Teluk Naga sebuah kecamatan dipesisir utara Laut Jawa merupakan salah satu kecamatan paling utara di Kabupaten Tangerang Provinsi Banten terdiri dari 13 desa yang potensial dengan potensi alam dan sumber daya manusia merupakan modal untuk menjadi kecamatan maju di semua bidang, antara lain bidang perikanan air laut/asin, payau, tawar. bidang

${ }^{1}$ Mukhtasor, Pencemaran Pesisir dan Laut, (Jakarta: Pradnya Paramita), 2007, hlm 2. 
pertanian. bidang pariwisata, bidang industri kecil/industri rumahan, menengah dan besarserta bidang-bidang lain yang dapat memberikan kemajuan perekonomian daerah.

Kecamatan ini bersebelahan dengan Kecamatan Kosambi yang berbatasan dengan DKI Jakarta, Kecamatan Pakuhaji, dan bersebrangan dengan Kecamatan Sepatan, berbatasan dengan Kota Tangerang yang terkenal dengan Bandara Internasional Soekarno Hatta, maka wajar jika kemajuan Teluk Naga akan menjadi target pengembangan industri dan perumahan untuk menanamkan investasi nya di beberapa desa di kecamatan Teluk Naga. Pada kondisi ini arus globalisasi dan mobilitas urban penduduk akan sangat tinggi yang akan merubah wajah Teluk Naga pelosok dan pesisir menjadi Teluk Naga maju sebagai sentra ekonomi.

\section{PERMASALAHAN}

Sehingga timbul permasalahan yang harus di selesaikan yakni bagaimana peran pemerintah daerah dan perlindungan hukum dalam upaya pengelolaan wilayah pesisir?

\section{METODOLOGI PENELITIAN}

Penulis akan menjawab permasalahan yang timbul mengenai peran pemerintah daerah dalam upaya pengelolaan wilayah peisisr serta perlindungan hukum yang dilakukan untuk upaya pengelolaan wilayah pesisir dengan melakukan penelitian hukum (Legal Research) yakni penelitian yang didasarkan pada suatu prosedur penelitian ilmiah untuk menemukan kebenaran berdasarkan logika hukum secara normatif, logika hukum dibangun berdasarkan disiplin ilmiah dan cara kerja ilmu hukum yang obyeknya adalah ilmu hukum itu sendiri.

Dalam menjawab permasalahan penulis juga melakukan penelitian langsung kelapangan dengan melakukan wawancara dan observasi terhadap wilayah pesisir khususnya di kecamatan Teluk Naga Kabupaten Tangerang.

Dan juga mempelajari berbagai peraturan perundang undangan hukum nasional dan kebijakan kebijakan yang dikeluarkan untuk pelaksanaan ketentuan tersebut meliputi : Undang-Undang Nomor I Tahun 2014 Tentang Perubahan Atas Undang-Undang Nomor 27 Tahun 2007 Tentang Pengelolaan Wilayah Pesisir dan Pulau-Pulau Kecil, Undang-undang Nomor 9 Tahun 2015 Tentang Perubahan Kedua Atas Undang-Undang Nomor 23 Tahun 2014 Tentang Pemerintah Daerah, dan 
Fikri Jamal

Undang-undang Nomor 32 Tahun 2009 tentang Perlindungan dan pengelolaan Lingkungan Hidup.

\section{PEMBAHASAN}

Tinjauan Umum Tentang Pemerintah Daerah, Wilayah Pesisir Dan Pengaturan Hukum Pengelolaan Wilayah Pesisir

Dalam Undang-Undang Dasar Negara Republik Indonesia Tahun 1945 (UUD 1945), pemerintahan daerah diatur dalam bab tersendiri yaitu dalam Bab VI dengan judul "Pemerintah Daerah". Dalam UndangUndang Dasar Republik Indonesia Serikat Tahun 1949, ketentuan mengenai hal itu termaktub dalam Pasal 42- 67 dan dalam Undang-Undang Dasar Sementara Tahun 1950 pada Pasal 13i dan 132. Bahkan sejak sebelum kemerdekaan, sudah banyak pula peraturan yang dibuat untuk mengatur mengenai persoalan pemerintahan di daerah dan persoalan yang berkaitan dengan soal desentralisasi. ${ }^{2}$

Hal ini berarti negara kesatuan harus dijalankan beriringan dengan otonomi daerah. Sentralisasi tidak boleh menghilangkan keberadaan otonomi daerah sebagai amanat konstitusi. Dalam Undang-Undang Nomor 23 Tahun 2014 tentang Pemerintahan Daerah yang sekarang telah dirubah menjadi Undang-Undang Nomor 9 Tahun 2015 Tentang Perubahan Kedua Atas Undang-Undang Nomor 23 Tahun 2014 Tentang Pemerintah Daerah, terdapat kecenderungan adanya arah sentralisasi. kecenderungan tersebut dapat diidentifikasi baik dari sisi konsep pembagian urusan, kewenangan pembentukan peraturan daerah, maupun dalam pembagian kewenangan khususnya untuk pengelolaan sumber daya alam, kehutanan, dan tambang. Konsideran Undang-Undang Nomor 23 Tahun 2014 tentang Pemerintahan Daerah menyatakan bahwa efisiensi dan efektivitas penyelenggaraan pemerintahan daerah perlu ditingkatkan dengan lebih memperhatikan aspek-aspek hubungan antara Pemerintah Pusat dengan daerah dan antardaerah, potensi dan keanekaragaman daerah, serta peluang dan tantangan persaingan global dalam kesatuan sistem penyelenggaraan pemerintahan negara.

Dalam Undang-Undang Nomor 23 Tahun 2014 tentang Pemerintahan Daerah terdapat Bab V (lima) yang mengatur tentang Pemerintahan Daerah Provinsi di laut dan Daerah Provinsi yang berciri kepulauan. Dalam Bab tersebut daerah provinsi diberi kewenangan untuk

${ }^{2}$ C.S.T. Kansil, Pokok-Pokok Pemerintahan di Daerah, Cetakan ke III, (Jakarta: Rineke Cipta), 1991, hlm 3. 
mengelola sumber daya alam laut yang berada di wilayahnya. Daerah provinsi yang berciri kepulauan melaksanakan kewenangan pemerintah pusat dibidang kelautan bedasarkan asas tugas perbantuan. Tetapi dalam $\mathrm{Bab}$ tersebut tidak memberi kejelasan mengenai kewenangan kabupaten/kota terkait pengelolaan wilayah laut. Dalam lampiran Undang-Undang Nomor 23 Tahun 2014 mengenai pembagian urusan bidang kelautan kabupaten/kota hanya diberikan kewenangan dalam perikanan tangkap, serta dalam hal perikanan budidaya.

Batasan pengertian wilayah pesisir dapat dijelaskan dengan menggunakan 3 pendekatan yaitu pendekatan ekologis, pendekatan perencanaan dan pendekatan administratif. Sedangkan secara praktis, batasan pengertian wilayah pesisir juga dapat dijelaskan berdasarkan praktek penentuan wilayah pesisir oleh berbagai negara, yang satu dengan lainnya dapat saling berbeda mengenai batasan ruang lingkupnya, yang tergantung dari kepentingan dan kondisi geografis pesisir masing-masing negara serta pendekatan yang digunakan

Pendekatan secara ekologis pada hakekatnya akan lebih memperlihatkan pengertian kawasan pesisir karena kawasan merupakan istilah ekologis, sebagai wilayah dengan fungsi utama yaitu fungsi lindung atau budi daya. ${ }^{3}$ Dalam hal ini kawaasn pesisir sebagai bagian dari wilayah pesisir merupakan zona hunian yang luasnya dibatasi oleh batas-batas adanya pengaruh darat ke arah laut. ${ }^{4}$ Demikian pula kawasan pesisir merupakan wilayah pesisir tertentu yang ditunjuk dan atau ditetapkan oleh pemerintah berdasarkan kreteria tertentu, seperti karakteristik fisik, biologi, sosial, dan ekonomi, untuk dipertahankan keberadaannya. ${ }^{5}$

Di sisi yang lain, ditinjau berdasarkan pendekatan dari segi perencanaan pengelolaan sumber daya yang difokuskan pada penanganan suatu masalah yang akan dikelola secara bertanggung jawab. Demikian pula untuk maksud perancanaan secara praktis, wilayah pesisir merupakan suatu wilayah dengan didukung oleh suatu karakteristik yang khusus, yang batas-batasnya seringkali ditentukan oleh masalah-masalah tertentu yang

${ }^{3}$ Pasal 1 butir 6, Undang-Undang Nomor 24 Tahun 1992 Tentang Penataan Ruang.

${ }^{4}$ Etty R. Agoes, Kebijakan Pengelolaan Kekayaan Alam Laut Secara Berkelanjutan, Suatu Tinjauan Yuridis, di dalam Beberapa Pemikiran hukum Memasuki Abad XXI, (Bandung: Angkasa), 1998.

${ }^{5}$ Pasal 1 butir 8 Undang-Undang Nomor 27 Tahun 2007 Tentang Pengelolaan Wilayah Pesisir dan Pulau-Pulau Kecil. 
Fikri Jamal

akan ditangani. ${ }^{6} \mathrm{Hal}$ itu disebabkan batas-batas wilayah pesisir sering kali ditentukan secara berubah-ubah yang berbeda luasnya di antara negaranegara dan sering kali didasarkan pada batas-batas jurisdiksi atau terbatas untuk alasan demi kelancaran dari segi administratif.

Dengan dikeluarkannya Undang-Undang No 32 Tahun 2004 Tentang Pemerintahan Daerah dalam Pasal i8 Ayat (4) disebutkan bahwa kewenangan untuk mengelola sumber daya di wilayah laut sebagaimana dimaksud pada ayat (3) paling jauh 12 (dua belas) mil laut diukur dari garis pantai kea rah laut lepas dan/atau kearah perairan kepulauan untuk propinsi dan $\mathrm{I} / 3$ (sepertiga) dari wilayah kewenangan propinsi untuk kabupaten/kota.

Berdasarkan Keputusan Menteri Kelautan dan Perikanan Nomor: KEP.ro/MEN/2002 tentang Pedoman Umum Perencanaan Pengelolaan Pesisir Terpadu, Wilayah Pesisir didefinisikan sebagai wilayah peralihan antara ekosistem darat dan laut yang saling berinteraksi, dimana ke arah laut 12 mil dari garis pantai untuk propinsi dan sepertiga dari wilayah laut itu (kewenangan propinsi) untuk kabupaten/kota dan ke arah darat batas administrasi kabupaten/kota. Menjamin keberlanjutan dari sumber daya yang terdapat diwilayah pesisir, pengelolaannya harus dilakukan secara terencana dan terpadu serta memberikan manfaat yang besar kepada semua pihak terutama masyarakat pesisir. ${ }^{7}$ Saat ini terdapat Undang-Undang Nomor 27 Tahun 2007 tentang Pengelolaan Wilayah Pesisir dan PulauPulau Kecil sebagaimana telah diubah dengan Undang-Undang Nomor I Tahun 2014 tentang Pengelolaan Wilayah Pesisir dan Pulau-Pulau kecil dan kebijakan kebijkan daerah yang diatur dalam peraturan daerah.

Dasar pemikiran dibuatnya undang-undang ini adalah terdapat kecenderungan bahwa Wilayah Pesisir dan Pulau-Pulau Kecil yang rentan mengalami kerusakan akibat aktivitas orang dalam memanfaatkan sumber dayanya atau akibat bencana alam. Selain itu akumulasi dari berbagai kegiatan eksploitasi yang bersifat parsial/sektoral di wilayah Pesisir dan Pulau-Pulau Kecil atau dampak kegiatan di hulu wilayah pesisir yang

${ }^{6}$ Kelly Rigg dalam L Tri Setyawanta, Konsep Dasar Dan Masalah Pengaturan Pengelolaan Pesisir Terpadu Dalam Lingkup Nasional, (Semarang: PSHL FH UNDIP), 2005, hlm 49 .

${ }^{7}$ Iqbal, M. (2018). IMPLEMENTASI EFEKTIFITAS ASAS OPORTUNITAS DI INDONESIA DENGAN LANDASAN KEPENTINGAN UMUM. Jurnal Surya Kencana Satu: Dinamika Masalah Hukum dan Keadilan, 9(1). 
didukung peraturan perundang-undangan yang ada sering menimbulkan kerusakan Sumber Daya Pesisir dan Pulau-Pulau Kecil. ${ }^{8}$

Keunikan Wilayah Pesisir dan Pulau-Pulau Kecil yang rentan berkembangnya konflik dan terbatasnya akses pemanfaatan bagi masyarakat pesisir dan pulau-pulau kecil, perlu dikelola secara baik agar dampak aktivitas manusia dapat dikendalikan dan sebagian wilayah pesisir dipertahankan untuk konservasi. 9

\section{Letak Geografis Pesisir Teluk Naga.}

Wilayah pesisir Kabupaten Tangerang terdiri atas delapan kecamatan yang memiliki wilayah pesisir, yaitu Kecamatan Keronjo, Kecamatan Kemiri, Kecamatan Mauk, Kecamatan Pakuhaji, Kecamatan Sukadiri, Kecamatan Dadap, Kecamatan Kosambi dan kecamatan Teluknaga. Dimana total panjang pantai wilayah ini adalah $5 \mathrm{r} \mathrm{Km}$ ( Rencana Strategis Wilayah Pesisir Dan Pulau-Pulau Kecill (RSWP-3K) Kabupaten Tangerang 2013-2032).

Kecamatan Teluknaga secaga geografis terletak diwilayah timur bagian utara pusat pemerintahan Kabupaten Tangerang atau disebelah utara Pulau Jawa. Berdasarkan luas wilayah Kecamatan Teluknaga tecatat sebesar $53.303 \mathrm{Km}$ yang meliputi i3 desa yaitu : Desa Babakan Asem, Desa Bojong Renged, Desa Kampung Besar, Desa Kampung Melayu Barat, Desa Kampung Melayu Timur, Desa Kebon Cau, Desa Lemo, Desa Muara, Desa Pangkalan, Desa Tanjung Burung, Desa Tanjung Pasir, Desa Tegal Anus dan Desa Teluk Naga. Secara umum kondisi tofografi Kecamatan Teluknaga merupaka dataran rendah dan pesisir pantai dengan ketinggian antara 0-7 mdpl yang terletak merata diseluruh Kecamatan Teluk Naga. Ada 3 desa yang termasuk kedalam desa pesisir yaitu Desa Tanjung Burung, Desa Tanjung Pasir, Desa Lemo dan Desa Muara.

\section{Potensi Sumber Daya Alam Pesisir Teluk Naga}

Perencanaan pembangunan wilayah merupakan suatu sajian atau gambaran keadaan masa mendatang mengenai wilayah secara efisien dan berkelanjutan. Perencanaan memuat tujuan dan sasaran pengelolaan wilayah dilandasi dukungan aspek kelembagaan dan peraturan pendukungnya, serta memuat uraian mengenai langkah-langkah stategis di dalam merumuskan dan mengaplikasikan kerangka teori kedalam

${ }^{8}$ Penjelasan Undang-Undang Nomor 27 Tahun 2007 Tentang Pengelolaan Wilayah Pesisir dan Pulau-Pulau Kecil

${ }^{9}$ Ibid 
Fikri Jamal

kebijakan ekonomi dan program pembangunan yang di dalamnya mempertimbangkan aspek wilayah dengan mengintegrasikan aspek social dan lingkungan menuju tercapainya kesejahteraan yang optimal dan berkelanjutan.

Pembangunan dibidang pesisir dan kelautan menjadi sangat penting, karena karakteristik wilayah pesisir memiliki keunikan dan kekhasan tersendiri dibandingkan wilayah-wilayah lain. Sumber daya yang terkandung di wilayah pesisir terdapat sumber daya manusia (human resource), dan sumber daya fisik (physical resource). Sumber daya manusia mencakup manusia itu sendiri yang jumlahnya, kualitasnya, pengetahuannya, dan keterampilannya, budayanya, fasilitas dan lembaga masyarakat yang terdapat didalamnya. Sumber daya fisik menackup sumber daya alam dan buatan, seperti waduk dan danau buatan. ${ }^{\text {IO }}$

Kecamatan Teluk Naga secara geografis memiliki letak yang strategis karena berbatasan langsung dengan Kota Tangerang dan memiliki aksesbilitas yang baik dengan ibukota DKI Jakarta yang menjadi salah satu potensi untuki berkembang menjadi daerah penyangga ibukota DKI Jakarta. Selain itu menjadi pintu gerbang antar provinsi Banten dan DKI Jakarta yang dapat menimbulkan interaksi yang menumbuhkan fenomena interdepedensi yang kemudian berdampak pada pertumbuhan suatu wilayah.

Kecamatan Teluk Naga sebagai wilayah pesisir memiliki manfaat yang penting bagi masyarakatnya. Melihat sumber daya manusia yang terdapat di kecanatan Teluk Naga umumnya kualitas sumber daya manusia relatif rendah, ini terlihat dari tingkat pendidikan yang terdapat di wilayah kecamatan Teluk Naga.

Rendahnya tingkat pendidikan berhubungan erat dengan dengan rendahnya kualitas sumber daya manusia di wilayah pesisir. Tingkat pendidikan di suatu daerah mengindikasikan tingkat sumbern daya manusia di daerah tersebut. Semakin tinggi jenjang pendidikan yang bisa diselesaikan oleh penduduk di suatu daerah, maka semakin tinggi pula tingkat pola piker masyarakatnya. Dengan semakin besar jumlah penduduk yang bisa menyelesaikan tingkat pendidikannya, maka daerah tersebut akan semakin maju.

Rendahnya kualitas sumber daya manusia di kecamatan Teluk Naga terlihat pula dari keterampilan yang dimiliki. Keterampilan mereka biasanya hanya menjadi nelayan. Hal ini tidak sebanding pada potensi

${ }^{10}$ http://smahiro.blogspot.co.id/2014/10/tes.html, di akses tanggal 15 Februari 2018 
yang dimiliki oleh kecamatan Teluk Naga. Keterampilan yang dimiliki masyarakat umumnya hanya terbatas pada satu sector saja yaitu penangkapan ikan sehingga kurang mengembangkan sektor lainnya.

Melihat daya dukung sumber daya manusia di kecamatan Teluk Naga masih relatif rendah, sebagai salah satu wilayah pesisir di kabupaten Tangerang yang memiliki potensi sumber daya pesisir yang cukup tinggi dan keanekaragamaan yang cukup tinggi, seharusnya dapat di imbangi dengan sumber daya manusia yang dapat berkembang atas kemampuan dan kekuatan sendiri, dengan mendasarkan pada pengembangan potensi alam dan lingkungan sekitar.

\section{Karakteristik Masyarakat Pesisir Teluk Naga}

Karakteristik masyarakat pesisir berbeda dengan karakteristik masyarakat agraris karena perbedaan sumber daya yang mereka hadapi atau miliki. Masyarakat agraris menghadapi sumber daya yang terkontrol yakni lahan untuk memproduksi suatu jenis komoditas dengan hasil yang dapat diprediksi. Dengan sifat yang demikian memungkinkan tetapnya lokasi produksi sehingga menyebabkan mobilitas usaha yang relatif rendah dan faktor resiko pun relatif kecil."

Sifat dan karakteristik masyarakat pesisir ditentukan oleh interaksi faktor-faktor sosial, ekonomi, dan lingkungan. Khususnya pada masyarakat nelayan, karakteristi yang mencolok adalah ketergantungan pada musim. Pada musim penangkapan nelayan sangat sibuk melaut. sebaliknya pada musim peceklik kegiatan melaut menjadi berkurang sehingga banyak nelayan yang terpaksa menganggur. ketergantungan pada musim ini semakin besar bagi nelayan kecil yang tidak mampu mengakses teknologi penangkapan. ${ }^{12}$ Dalam mempertahankan kehidupannya, sistem jaminan sosial membentuk apa yang dikenal hubungan patron-klien. Pada musim paceklik nelayan kecil, buruh nelayan, petani tambak kecil, dan buruh tambak seringkali terpaksa meminjam uang atau barang untuk kebutuhan hidup sehari-hari pada juragan atau pada pada para pedagang pengepul. Hal ini juga terjadi pada masyarakat Teluk Naga, yang Notabene jumlah nelayan kecil banyak terdapat pada daerah ini. Selain itu faktor kenaikan BBM juga menjadai kendala bagi nelayan, berbagai upaya untuk menekan biaya melautpun dilakukan seperti mengganti solar dengan

11 http://www.psychologymania.com/2013/05/karakteristik-masyarakat-pesisir.html, diakses tanggal 12 Februari 2018

${ }^{12}$ Iwan Nugroho dan Rokhmin Dahuri, "Pembangunan wilayah perspektif Ekonomi, sosial dan Lingkungan", (Jakarta: LP3eS), 2002, hlm 250 
Fikri Jamal

minyak tanah, itupun masih dibayang-bayangi kenaikan BBM yang terus menerus.

Pasar adalah faktor penting yang mempengaruhi karakteristik masyarakat pesisir. Berbeda dengan petani padi yang dapat menyimpan sebagian panennya untuk mencukupi kebutuhan sendiri, para nelayan dan petani tambak harus menjual sebagian hasilnya secara cepat karena sifat produk perikanan yang kurang tahan lama, kecuali jika tersedia fasilitas pengolahan atau pengawetan, maka keadaan pasar sangat mempengaruhi harga ikan dan tingkat pendapatan nelayan yang sangat mempengaruhi kondisi sosial ekonomi masyarakat pesisir. Sarana perdagangan di kecamatan ini belum banyak berkembang. Umumnya berupa toko dan pasar tradisional yang melayani kebutuhan sehari-hari serta pasar hewan. Belum terlihat pusat-pusat grosir atau pusat pemasaran industri kecil untuk memudahkan akses pemasaran.

Sebelum lahirnya Undang-Undang Nomor 23 Tahun 2014 tentang Pemerintahan Daerah, Tangerang wilayah Utara sebagai wilayah pesisir memiliki kewenangan untuk sumber daya di wilayah laut, termasuk menata ruang dan mengelola area pasca reklamasi. Karenanya yang semula Pemerintah Kabupaten Tangerang bersama masyarakat Tangerang wilayah utara meyakini bahwa melalui Peraturan Darerah Kabupaten Tangerang Nomor 8 Tahun 2006 tentang Penyelenggaraan Reklamasi Untuk Kawasan Pengembangan Perkotaan Baru (KPPB) untuk merealisasikan proyek raksasa Reklamasi Laut kurang lebih 9.ooo Ha pada area sepanjang pantai Tangerang wilayah Utara yang diukur mulai $200 \mathrm{~m}$ sampai kedalaman laut maksimal 8 (delapan) meter dari tinggi muka air laut rata-rata, akan mampu meningkatkan bukan saja perekonomian masyarakat Tangerang wilayah utara tetapi juga akan signifikan meningkatkan pendapatan anggaran daerah Pemerintah Kabupaten Tangerang.

Pembangunan ekonomi daerah harus dapat memaksimalkan seluruh potensi. Bila pemerintah daerah telah menyiapkan instrumen bagi pembangunan daerah, bila sumber daya alam sudah tersedia, akan tetapi apakah para pelaku ekonomi non pemerintah tertarik untuk menginvestasikan financial-nya pada daerah dengan sumber daya alam yang tersedia tersebut.

APBD saja tidak lagi cukup untuk membiayai pembangunan suatu daerah dengan segala infrastrukturnya, karena pertumbuhan penduduk, kemajuan teknologi, dan kompleksitas teritorial.

Karenanya, keterlibatan pelaku ekonomi telah menjadi pilihan banyak daerah dari pada mengandalkan APBD (from government to 
governance). Pemerintah Daerah diharapkan tidak saja menerapkan fungsi managemen birokrasi, akan tetapi juga diharapkan dapat menerapkan praktik kewirausahaan. Karenanya, pemerintah daerah tidak berjalan sendiri, tetapi berkolaborasi dengan banyak pihak khususnya pelaku ekonomi (investor).

Lihat saja contoh yang sangat aktual, betapa wilayah Desa-desa di Kecamatan Pagedangan dan Desa-desa di Kecamatan Cisauk, dalam 20 tahun kebelakang, Desa-desa di 2 (dua) Kecamatan tersebut hampir tidak dikenal oleh kita masyarakat di Tangerang Utara. Saya meyakini bahwa pada Tahun 1995, Kecamatan Kosambi dengan area Bandara Soekarno Hatta-nya, Teluknaga dengan wisata Tanjung Pasirnya, bahkan Kronjo dengan Pulau Cangkirnya jauh lebih dikenal dari pada (dua) wilayah di Kecamatan Pagedangan dan Kecamatan Cisauk.

Hal ini yang menarik perhatian penulis untuk melakukan penelitian kedaerah pesisir khususnya kecamatan Teluk Naga untuk mengamatai mengapa pembangunan di daerah pesisir sangat lambat dan tidak terlaksana dengan baik.

Pesatnya pembangunan kawasan komersial (BSD, Paramount dan Summarecon) di Kecamatan Pagedangan, Kelapa Dua dan Cisauk, bukan saja masyarakat Kabupaten Tangerang yang mengenal kawasan tersebut, tetapi kawasan ini juga dikenal luas dan dikunjungi oleh masyarakat Kota Tangerang, Kota Tangerang Selatan, DKI Jakarta, Serang, Cilegon, Pandeglang, Lebak bahkan Turis Manca Negara banyak membelanjakan uang-nya di Kawasan ini.

Betapa perputaran uang tidak hanya bermilyar-milyar di kawasan ini, tetapi juga sudah bertrilyun-trilyun. Dan pada gilirannya, banyak menyerap tenaga kerja yang berasal dari penduduk lokal di sekitar kawasan ini. Pendapatan Perkapita penduduk lokal bertambah, kesejahteraan penduduk lokal meningkat, daya beli penduduk lokal terjangkau.

Membangun kota baru berarti menciptakan pusat pertumbuhan baru, menarik investasi, dan selanjutnya menciptakan lapangan pekerjaan baru. Dengan demikian, daerah dapat memainkan peran untuk menjadi fasilitator bagi pembangunan daerahnya.

\section{Peran Pemerintah Daerah Dalam Pengelolaan Wilaayah Pesisir di Kecamatan Teluk Naga.}

Undang-Undang Nomor I Tahun 2014 Tentang Perubahan Atas Undang-Undang Nomor 27 Tahun 2007 Tentang Pengelolaan Wilayah Pesisir dan Pulau-Pulau Kecil sudah mengamanatkan bahwa kawasan 
konservasi di wilayah pesisir dan pulau-pulau kecil termasuk suaka alam dan kawasan pelestarian alam yang berada di wilayah pesisir dan pulaupulau kecil dalam bentuk Taman Nasional/Taman Nasional Laut, suaka Margasatwa. Sebagaimana penjelasan Pasal 78A Undang-Undang Nomor I tahun 20I4.

Lembaga pengelola kawasan konservasi. Secara hukum sudah diatur peralihan kawasan konservasi dari kementerian Lingkungan Hidup dan Kehutanan ke KKP namun dalam prakteknya di lapangan masih dikelola oleh PHKA (KLHK). Pengalihan kelembagaan yang berlarut-larut akan menimbulkan tidak efektif dan tidak efisien berjalannya organisasi.

Kewenangan penangkapan berdasarkan KUHAP dan UndangUndang Nomor I Tahun 2014 Tentang Perubahan Atas Undang-Undang Nomor 27 Tahun 2007 Tentang Pengelolaan Wilayah Pesisir dan PulauPulau Kecil diberikan hanya kepada penyidik Polri. Undang-Undang Nomor I Tahun 2014 Tentang Perubahan Atas Undang-Undang Nomor 27 Tahun 2007 Tentang Pengelolaan Wilayah Pesisir dan Pulau-Pulau Kecil tidak secara eksplisit memberikan kewenangan penangkapan terhadap PPNS KKP apabila PPNS tersebut menemukan pelanggaran hukum di wilayah pesisir. Kewenangan penangkapan baru diberikan pada level peraturan menteri, seharusnya kewenangan penangkapan merupakan substansi Undang-Undang Nomor I Tahun 2014 Tentang Perubahan Atas Undang-Undang Nomor 27 Tahun 2007 Tentang Pengelolaan Wilayah Pesisir dan Pulau-Pulau Kecil.

Adanya pengakuan pemerintah terhadap masyarakat adat sesuai dengan peraturan perundang-undangan. Apakah untuk dapat disebut sebagai masyarakat hukum adat perlu mendapatkan pengakuan, hal ini terkait dengan hak-hak masyarakat adat di wilayah tersebut, bagaimanakah bentuk pengaturan pengakuan tersebut. Perlu pengaturan masyarakat hukum adat yang tidak mendelegitemasi masyarakat hukum adat. Jika tidak, masyarakat hukum adat dapat semakin tergerus eksistensinya apabila tidak diberikan pengaturan yang seharusnya.

\section{Upaya Perlindungan Hukum Dalam Pembangunan Wilayah Pesisir di Kecamatan Teluk Naga.}

Pengesahan Undang-Undang Nomor 23 Tahun 2014 tentang Pemerintah Daerah yang mencabut Undang-Undang Nomor 32 Tahun 2004 tentang Pemerintag Daerah dan yang sekarang telah dirubah menjadi Undang-Undang Nomor 9 Tahun 2015 Tentang perubahan kedua atas Undang-Undang Nomor 23 Tahun 2014 tentang Pemerintah Daerah berdampak terhadap otonomi daerah dalam pengelolaan pesisir dan pulau- 
pulau kecil. Pasal 27 ayat (I) Undang-Undang Nomor 23 Tahun 2014 tentang Pemerintah Daerah menyebutkan bahwa Daerah Provinsi diberikan kewenangan untuk mengelola sumber daya laut yang ada di wilayahnya. Pasal ini menggugurkan Pasal i8 ayat I Undang-Undang Nomor 32 Tahun 2004, yang menyebutkan bahwa Daerah yang memiliki wilayah laut diberikan kewenangan untuk mengelola sumber daya di wilayah laut. Pada bagian penjelasan, Daerah dalam Undang-Undang Nomor 32 Tahun 2004 adalah Pemerintah Provinsi dan Pemerintah Kabupaten/Kota. Dengan demikian, secara langsung Pasal 27 ayat (I) Undang-Undang Nomor 23 Tahun 2014 mencabut kewenangan Kabupaten/Kota dalam pengelolaan sumber daya laut.

Adapun kewenangan Daerah Provinsi untuk mengelola sumber daya di wilayah laut sebagaimana tertuang dalam Pasal 27 ayat (2) UndangUndang Nomor 23 Tahun 2014.

Dalam pengelolaan wilayah pesisir pemerintah daerah harus memperhatikan pemberdayaan masyarakat, sebagimana diatur dalam pasal 63 Undang-Undang Nomor I tahun 2014 tentang perubahan atas undangundang nomor 27 tahun 2007 tentang pengelolaan wilayah pesisir dan pulau-pulau kecil

Adapun dalam penerapan sanksi terhadap segala bentuk pelanggaran yang terjadi di wilayah pesisir diatur dengan sanksi administrative dan sanksi pidana sebagimana di atur dalam pasal 71-75 Undang-undang Nomor I Tahun 2014 tentang perubahan atas Undang-undang Nomor 27 Tahun 2007 tentang pengelolaan wilayah pesisir dan pulau pulau kecil.

\section{KESIMPULAN}

I. Peran pemerintah daerah terhadap pengelolaan wilayah pesisir khususnya wilayah pesisir utara Kabupaten Tangerang pada Kecamatan Teluk Naga, secara lebih tegas aturan mengenai pengelolaan wilayah pesisir di atur dalam Undang-Undang Nomor I Tahun 2014 tentang perubahan atas undang-undang nomor 27 tahun 2007 tentang pengelolaan Wilayah Persisir dan Pulau-Pulau Kecil mengenai peran pemerintah terdapat dalam pasal I angka 42 dimana Pemerintahan Daerah adalah penyelenggaraan urusan pemerintahan menurut asas otonomi Pemerintah Daerah juga berperan penting dalam pemberdayaan masyarakat sebagaimana di atur dalam Pasal 63 Undang-Undang Pengelolaan Wilayah Pesisir dan Pulau -Pulau Kecil.

2. Dalam perlindungan hukum terhadap pengelolaan wilayah pesisir Undang-Undang Nomor I tahun 2014 tentang perubahan atas undang- 
Fikri Jamal

undang nomor 27 tahun 2007 tentang pengelolaan wilayah pesisir dan pulau-pulau kecil menetapkan sanksi administratif dan sanksi pidana. Dimana untuk sanksi administratif diatur dalam pasal 71-72 dan untuk sanksi pidana diatur dalam pasal 73-75 Undang-undang pengelolaan wilayah pesisir dan pulau-pulau kecil.

\section{DAFTAR PUSTAKA}

Asrul Pramudya, Kajian Pengelolaan Daratan Pesisir Berbasis Zonasi di Provinsi Jambi, (Semarang: Tesis Pasca Sarjana Magister Teknik Sipil Universitas Diponegoro), 2008.

Bernard L Tanya dkk, Teori Hukum: Strategi Tertib Manusia Lintas Ruang dan Generasi, (Yogyakarta: Genta Publising), 2013.

Bernard L. Tanya, Teori Hukum, Strategi Tertib Manusia Lintas Ruang dan Generasi, (Yogyakarta: Genta Publishing), 2013.

Emil Salim, Lingkungan Hidup, (Jakarta: Mutiara Sumber Widya), 1985.

Iqbal, M. (2018). IMPLEMENTASI EFEKTIFITAS ASAS OPORTUNITAS DI INDONESIA DENGAN LANDASAN KEPENTINGAN UMUM.Jurnal Surya Kencana Satu: Dinamika Masalah Hukum dan Keadilan, 9(I).

Iqbal, Muhamad. "Perkembangan Kejahatan Dalam Upaya Penegakan Hukum Pidana: Penanggulangan Kejahatan Profesional Perdagangan Organ Tubuh Manusia." PROCEEDINGS. Vol. 2. No. I. 2017.

Jimly Asshiddiqie, Pokok-Pokok Hukum Tata Negara Indonesia Pasca Reformasi, (Jakarta: Bhuana Ilmu Populer), 2007.

K.E.S. Manik, Pengelolaan Lingkungan Hidup, (Jakarta: Djambatan), 2003.

Koesnadi Hardjasoemantri, Hukum Tata Lingkungan, (Yogyakarta: Gadjah Madah University Press), 2009.

Lili Rasyidi dan I. B. Wyasa Putra, Hukum Sebagai Suatu Sistem, (Bandung: CV. Mandar Maju), 2003.

Mattulada, Latoa, Suatu Lukisan Analisis Terhadap Antropologi Politik Orang Bugis, (Makassar: Hasanuddin University Press), 2007.

Mochtar Kusumaatmadja, Hukum, Masyarakat, dan Pembinaan Hukum Nasional, (Bandung: Binacipta), 1995. 
Mochtar Kusumaatmadja, Konsep-Konsep Hukum Dalam Pembangunan (Kumpulan Karya Tulis), (Bandung: Alumni), 2002.

Mochtar Kusumaatmadja, Pembinaan Hukum Dalam Rangka Pembangunan Nasional, (Bandung: Binacipta), 1986.

Mukhtasor, Pencemaran Pesisir dan Laut, (Jakarta: Pradnya Paramita), 2007 .

Munadjat Danusaputro, Bina Mulia Hukum dan Lingkungan, (Bandung: Binacipta), 2004.

Peter Mahmud Marzuki, Pengantar Ilmu Hukum, (Jakarta: Prenada Media Group), 2009.

Satjipto Rahardjo, Ilmu Hukum, (Bandung: PT Citra Aditya Bakti), 2012.

Shidarta, Karakteristik Penalaran Hukum Dalam Konteks Ke-Indonesian, (Jakarta: CV Utomo), 2006.

Yovita A. Mangesti \& Bernard L. Tanya, Moralitas Hukum, (Yogyakarta: Genta Publishing), 2014.

Undang-Undang Dasar Republik Indonesia Tahun 1945.

Undang-Undang Nomor 26 Tahun 2007 tentang Penataan Ruang.

Undang-Undang Nomor I Tahun 2014 Tentang Pengelolaan Wilayah Pesisir dan Pulau-Pulau Kecil.

Undang-Undang Nomor 45 Tahun 2009 tentang Perikanan.

Undang-Undang Nomor 9 Tahun 2015 Tentang Pemerintahan Daerah.

Peraturan Pemerintah Nomor 26 Tahun 2008 tentang Rencana Tata Ruang Wilayah Nasional. 

